\title{
The fall armyworm Spodoptera frugiperda (J.E. Smith), a new pest of maize in Africa: biology and first native natural enemies detected
}

\author{
Etienne TENDENG ${ }^{1,2, *}$, Babacar LABOU ${ }^{1}$, Mamadou DIATTE $^{1}$, Saliou DJIBA ${ }^{2}$ and \\ Karamoko DIARRA ${ }^{1}$ \\ ${ }^{I}$ UCAD, Laboratoire Production et Protection Intégrées en Agroécosystèmes Horticoles - L2PIA, Faculté des \\ Sciences et Techniques, Dakar, Sénégal. \\ ${ }^{2}$ ISRA, Centre de Recherches Agricoles de Djibélor, B.P 34, Ziguinchor, Sénégal. \\ *Auteur correspondant ; E-mail: etienne.tendeng@ucad.edu.sn; Tel : +221-77-701-04-09
}

\begin{abstract}
The fall armyworm (FAW), Spodoptera frugiperda is a real threat to food security. It is able to totally destroy the cereal crops in a country. It can cause famine in Sub-Saharan Africa where cereals are subsistence crops. Reported in Africa in 2016, the FAW succeded to colonize 47 countries in one year. Its migration capacities wich are of around $100 \mathrm{~km}$ per night can allow it have fully infest a country like Senegal (ca 200000 $\mathrm{km}^{2}$ ) in less than a week. The FAW is very difficult to fight because resistant to several insecticides. Invasive species often invade a new environment without their natural enemies, which promotes their multiplication and damage to crops. To estimate the generation number per year and evaluate the impact of biological control of indigenous natural enemies on the FAW, larvae were collected in maize fields and monitored in the laboratory. The results show that the development cycle of $S$. frugiperda takes 25 days on average, that is to say fifteen (15) generations per year. The study confirms the presence of three species of native natural enemies, a nematode Hexamermis sp. and two Hymenopterans Chelonus sp. and Campoletis sp. detected for the first time in West Africa on FAW larvae. The overall parasitism rate is $25.8 \%$. These native natural enemies are a very promising means of control against FAW populations. The introduction of agricultural techniques to promote the maintenance and the proliferation of the FAW auxiliaries is an alternative to the use of pesticides.
\end{abstract}

(C) 2019 International Formulae Group. All rights reserved

Keywords: Invasive insect, natural regulation, insect conservation, Senegal, food security, cereals.

\section{INTRODUCTION}

In sub-Saharan Africa, food security is a development issue. Cereals remain the main subsistence food for people mostly poor (OCDE/FAO, 2016). Cereal production is threatened by several factors, namely climatic variability and invasive pests including Spodoptera frugiperda (Lepidoptera Noctuidae) (Day et al., 2017). The fall armyworm, S. frugiperda is a dangerous pest of cereals detected in Africa in 2016 (Goergen et al., 2016). Since then, S. frugiperda has been invading Sub-Saharan Africa countries. The larvae of this pest can totally destroy the cereal crops. This pest invasion seems fast and efficient thanks to a great migratory capacity of up to $100 \mathrm{~km}$ per night (FAO, 2017). In Senegal, the species $S$ frugiperda has been 
reported by (Brévault et al., 2018). During the same period our surveys have helped find $S$. frugiperda in Casamance, in southern Senegal (pers.comm E.TENDENG, September, 2017.). A study of its previously unrecognized bioecology in Africa is carried out to estimate the annual generation number. The difficulty of managing the pest related to a misunderstanding of its biology and associated auxiliary fauna is a real challenge to rise up. According to (Nagoshi et al. 2017), the invasion of $S$. frugiperda in Africa has two major consequences. The pest is found in a new area where its natural enemies are absent, which would favor an initial period of rapid population growth and dispersal, with negative impacts on agriculture. The pest may have new resistance traits in its new environment, which puts the crops at risk. The incertitude related to the behavior of the insect in a new environment and the absence of phytosanitary treatments of major crops in Senegal, especially for maize, make that chemical control remains ineffective. In addition, S. frugiperda can easily develop resistance to insecticides (organophosphates, pyrethroids, carbamates, etc.) (Yu, 1991). Conservation biological control, which fosters the optimal use of indigenous natural enemies, is a promising way for reducing pesticide reliance (Labou et al., 2016b). Biological control would be an alternative to manage $S$. frugiperda.

The purpose of this study was to contribute to the control of the invasive pest $S$. frugiperda. Specifically, we evaluated the duration of the development cycle of $S$. frugiperda and also determined the parasitism rate by natural enemies.

\section{MATERIELS AND METHODS}

\section{Biology of Spodoptera frugiperda} Sampling and determination of the duration of the development cycle of $S$. frugiperda

The sampling was done every 15 days in a maize field located at Boudialabou in Casamance (Senegal). The sampled larvae are returned to the laboratory, isolated in boxes and fed with fresh corn leaves until nymphosis. Nymphs obtained are individually isolated in boxes and followed until the emergence of an adult of $S$. frugiperda, a parasitoid or parasite.

The eggs laid were monitored daily to know their hatching day. The neonate larvae were also followed until nymphosis to determine the duration of the development of the larval phase. The duration of the nymphal phase was determined by daily monitoring of nymphs until the emergence of adults. The lifetime of adults was shown by following newly emerged adults until they die.

Identification of developmental stages of $S$. frugiperda

The main development stages (egg, larvae, nymph and adult) were observed using a binocular magnifying glass equipped with a graduated scale. The photos were taken with the "Dinolite" to better visualize individuals. Eggs were measured and counted. Young larvae were described and the size of the cephalic capsule were measured. The size of neonate larvae and that of late larval stages were measured. Pupae were observed and described. Their size was measured. The emerged adults were killed with ethyl acetate and then spread to measure their wingspan.

Identification of natural enemies of Spodoptera frugiperda and determination parasitism rate

Parasitoids and parasites identification of $S$. frugiperda

The main stages of development of parasitoids and parasites are identified. For parasitoids, the total length of the body, wings, antennas and abdomen is measured. Identification keys proposed by Van Achterberg (1990) and Braet et al.(2012) were used to identify parasitoids. Parasitic nematodes were spread out and their length measured. The determination keys proposed by Nickle (1972) and Baker and Capinera (1997) were used for their identification.

Determination of parasitism rate of parasitoids and parasites of S. frugiperda

The parasitism rate was determined by relating the number of auxiliaries (parasitoids and parasites) to the total number of larvae collected and monitored. The percentage of 
parasitism was calculated using $\mathrm{Mc}$ Cutcheon's formula (1987)

Parasitism rate

$=\left[\frac{\text { Number of parasitized larvae }}{\text { (NLC }- \text { NDL) }}\right] X 100$

NLC: Number of Larvae Collected

NDL: Number of Dead larvae without

parasitism

\section{RESULTS}

Biology of Spodoptera frugiperda

Duration of the development cycle of $S$. frugiperda in laboratory

In laboratory, the total duration cycle of $S$. frugiperda is between 22 and 28 days at $25^{\circ} \mathrm{C}$ with an average of 25 days. The number of generations per year is between 13 and 17 generations per year with an average of 15 generations (Table 1).

The incubation of the eggs last in 5 days ( $\pm 1 \mathrm{~d})$. The duration of development of the larval phase is between 13 and 15 days with an average of 14 days while that of the nymphal phase is 7 days on average. The lifetime of adults is 31 days on average.

\section{Identification of the development stages of $S$. frugiperda}

The eggs, 400 in number, measure between 0.3 and $0.4 \mathrm{~mm}$. They form a mass consisting of two layers (Figure 1b). The young larvae are light in color. The black cephalic capsule measures $0.15 \mathrm{~mm}$ on average (Figure 1c) and has a dark cervical shield. Sidebands appear gradually from the third larval stage of neonates. In the last larval stage, the size of larvae is variable. The average size is $0.6 \mathrm{~mm}$ for neonate larvae. The average size of larvae of last larval stage is $43.9 \mathrm{~mm}$ (Figure 1d). The pupae are brown in color with a very pronounced shine. The length of the pupae varies between 14 to 18 $\mathrm{mm}$ (Figure 1f). Size of adults vary between 32 to $40 \mathrm{~mm}$ wings pan (Figure 1a).

Emerging adults were sexed. Sexage was based on the color of the wings. The female has anterior wings colored gray-brown with indistinct whitish spots. In the male the gray-brown color is more contrasted with whitish spots.
Identification and rate of parasitism of the natural enemies of Spodoptera frugiperda Parasitoids and parasites identified on the moth

Despite its recent introduction into West African territory, S. frugiperda already has a large number of parasites such as nematods and hymenopterans (Table 2).

\section{The Nematodes}

Nematodes of genus Hexamermis (Figure 2c-e) emerged from the S. frugiperda larvae collected in the field. Out of a total of 290 larvae of $S$. frugiperda collected, 35 larvae died without parasitoids emerging. A total of 35 individuals were obtained from a total of 255 larvae. This gives a rate of parasitism estimated at $13.7 \%$. For nematodes, the emergence of 2-4 individuals per host has sometimes been observed. In this case, the parasitism calculation considers only one individual. Adult nematodes have a length which ranges from 100 to $120 \mathrm{~mm}$ (Table 2).

\section{The Hymenopterans}

Hymenopterans of the genus Chelonus and Campoletis were obtained from larvae of $S$. frugiperda. These two hymenoptera are solitary parasitoids. A total of 28 individuals of the parasitoid Chelonus sp. was obtained on a number of 255 larvae of the pest. Its rate of parasitism was calculated, giving a percentage of 10.9. For the species Campoletis sp., only three (3) individuals emerged from the 255 larvae of the $S$. frugiperda sampled. Its rate of parasitism is $1.2 \%$ (Table 2).

Adults of the parasitoid Chelonus sp. that have emerged have a size that ranges from 8 to $9 \mathrm{~mm}$ (Figure 3f). They are characterized by the presence of two white spots in the anterior part of the abdomen. The relationship between antenna length and the body length and that of the wing and body are respectively $0.8 \mathrm{~mm}$ and $0.75 \mathrm{~mm}$.

The species Campoletis sp. has long antennas (Figure 4a). They are longer than the body and vary from 7 to $8 \mathrm{~mm}$. The length of the body varies from 6 to $7 \mathrm{~mm}$. The forewings are between 5.7 to $5.9 \mathrm{~mm}$ 
Table 1: Size and Life span of the main stages of development of $S$. frugiperda elevated in laboratory at $25 \pm 1{ }^{\circ} \mathrm{C}, \mathrm{HR} 65 \pm 5 \%$, Photoperiod $12 \mathrm{~h}$.

\begin{tabular}{cll}
\hline Stages & Length & Duration \\
\hline Eggs & $0.4 \pm 0.1 \mathrm{~mm}$ & $\begin{array}{l}5 \pm 1 \text { days } \\
\text { (Incubation) }\end{array}$ \\
\hline Larvae & $0.6 \pm 0.2 \mathrm{~mm}$ (neonate stage) & $\begin{array}{l}14 \pm 1 \text { day } \\
\text { (Larval phase) }\end{array}$ \\
& $43.9 \pm 0.2 \mathrm{~mm}$ (Last stage) & $\begin{array}{c}7 \pm 1 \text { days } \\
\text { (Nymphal phase) }\end{array}$ \\
\hline Pupae & $14 \pm 0.1 \mathrm{~mm}$ & $\begin{array}{l}16 \pm 1 \text { days } \\
\text { (Adult phase) }\end{array}$ \\
\hline Adults & $31 \pm 2 \mathrm{~mm}$ & $\begin{array}{l}26 \pm 3 \text { days } \\
\text { (Total duration of the cycle) }\end{array}$ \\
\cline { 2 - 2 } & &
\end{tabular}

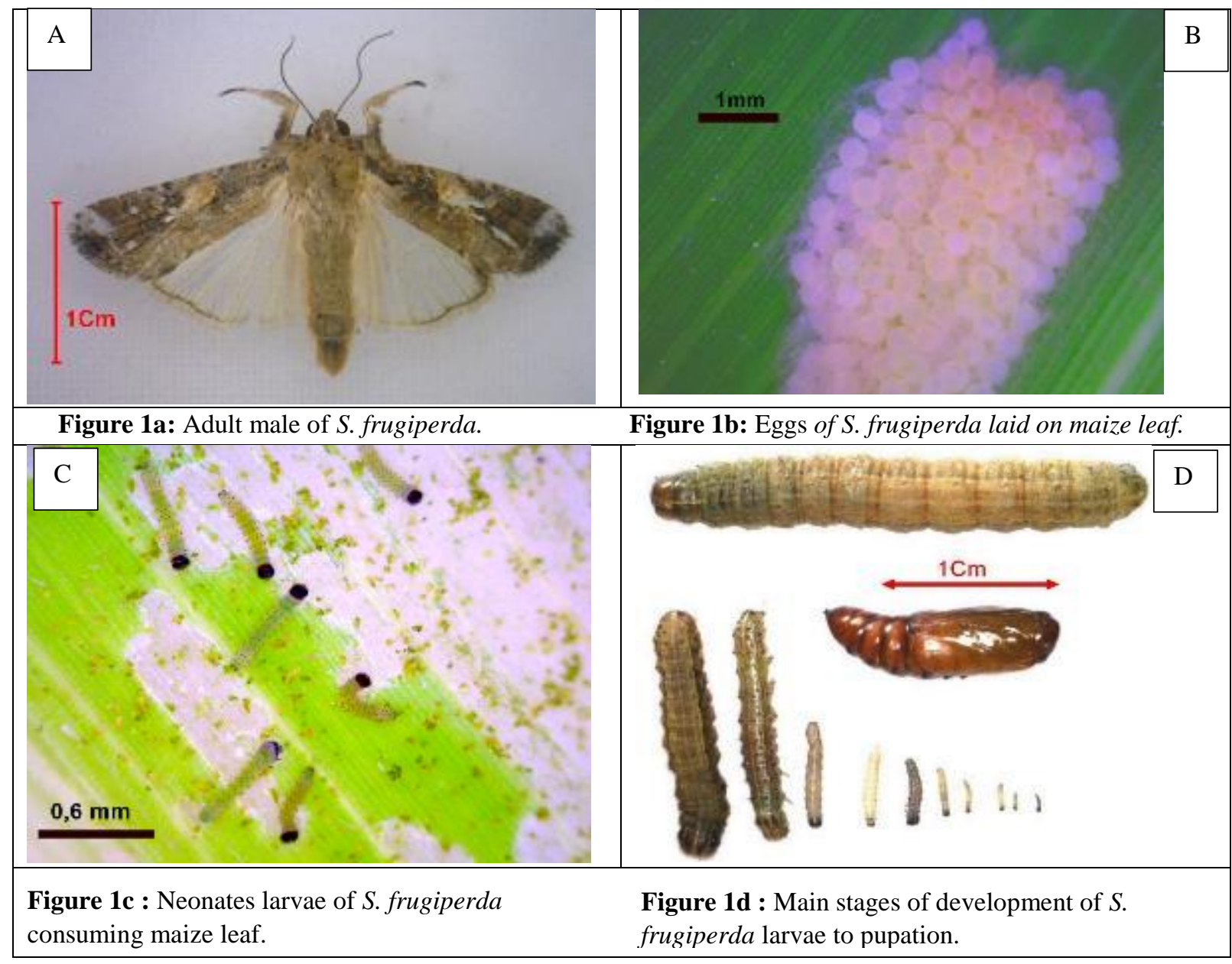




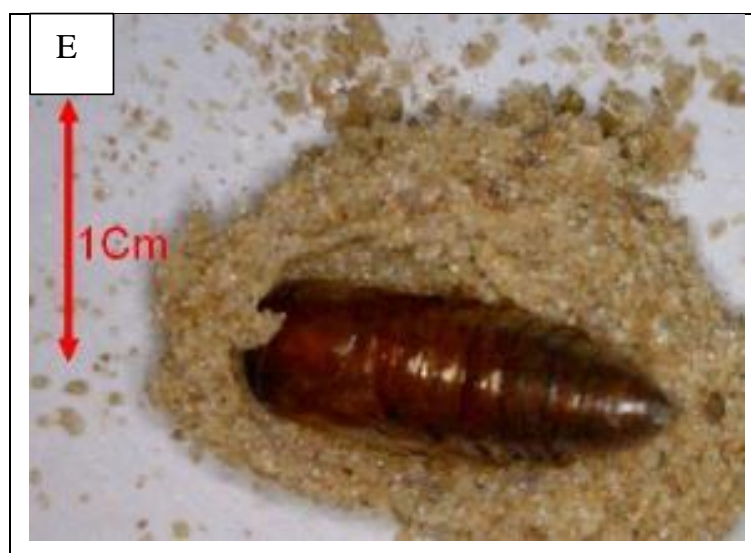

Figure 1e : Nymph of S. frugiperda from a loose soil maize field.

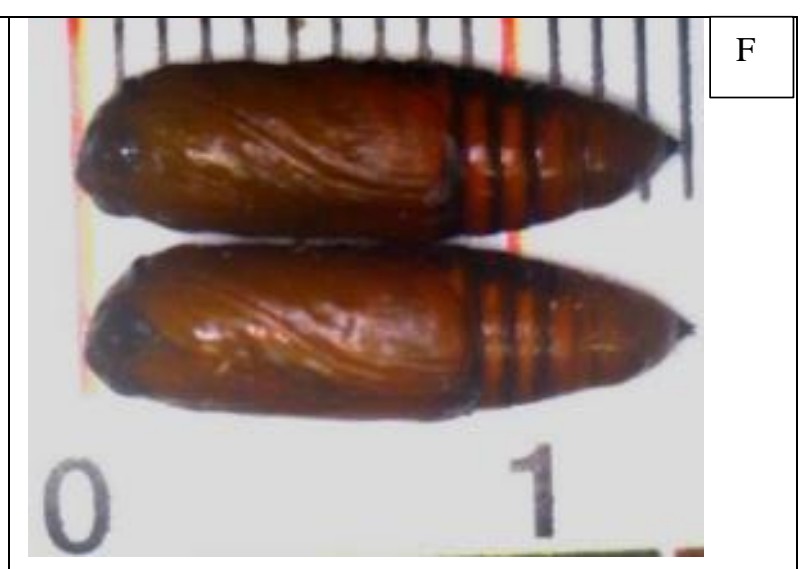

Figure 1g: Nymphs of S. frugiperda measured in the laboratory.

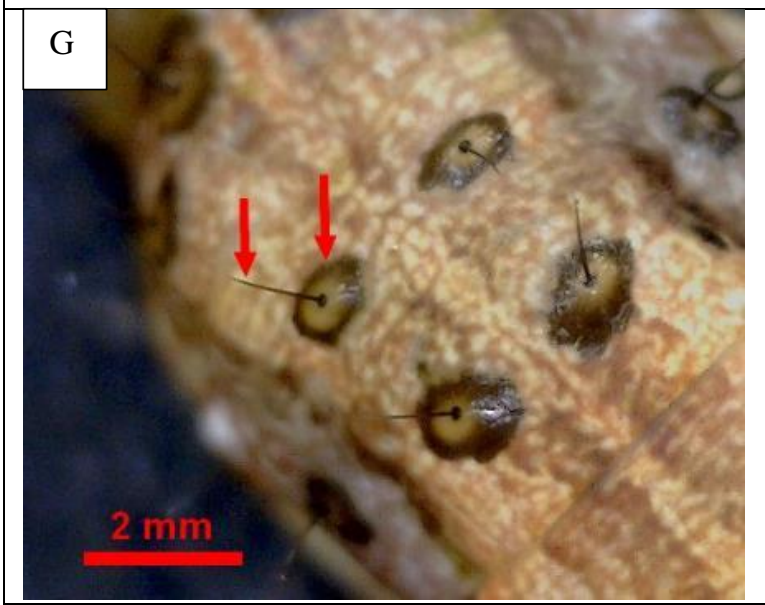

Figure 1f: Pinaculas of $S$. frugiperda larva arranged as a square.

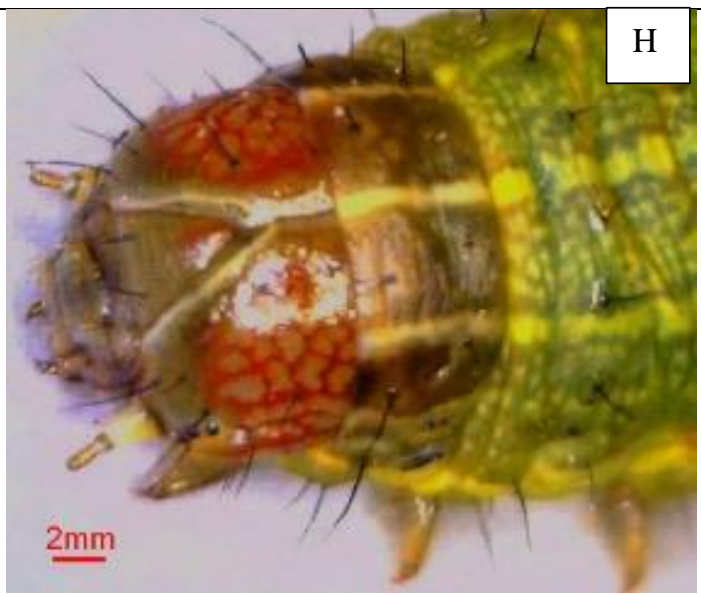

Figure 1h: Cephalic capsule of S. frugiperda larvae with a lighter inverted "Y".

Table 2: Life span and parasitism rates of the main parasitoid hymenopterans and parasite nematodes observed on $S$. frugiperda monitored at the laboratory at $25 \pm 1{ }^{\circ} \mathrm{C}$, HR $65 \pm 5 \%$, Photoperiod $12 \mathrm{~h}$.

\begin{tabular}{|c|c|c|c|}
\hline Auxiliaries & Number * & Life span of adults & $\begin{array}{c}\text { Parasitism } \\
(\%)\end{array}$ \\
\hline $\begin{array}{l}\text { HYMENOPTERA PARASITOID } \\
\text { Ichneumonidae } \\
\quad \text { Campoletis } \mathrm{sp} .\end{array}$ & 3 & $7 \pm 2$ days & 1.2 \\
\hline $\begin{array}{l}\text { HYMENOPTERA PARASITOID } \\
\text { Braconidae } \\
\text { Chelonus } \text { sp. }\end{array}$ & 28 & $8 d \pm 1$ day & 10.9 \\
\hline $\begin{array}{l}\text { NEMATODE PARASITE } \\
\text { Mermithidae } \\
\quad \text { Hexamermis sp. } \\
\end{array}$ & 35 & $120 \pm 5$ days & 13.7 \\
\hline & Tot & al parasitism & 25.8 \\
\hline
\end{tabular}




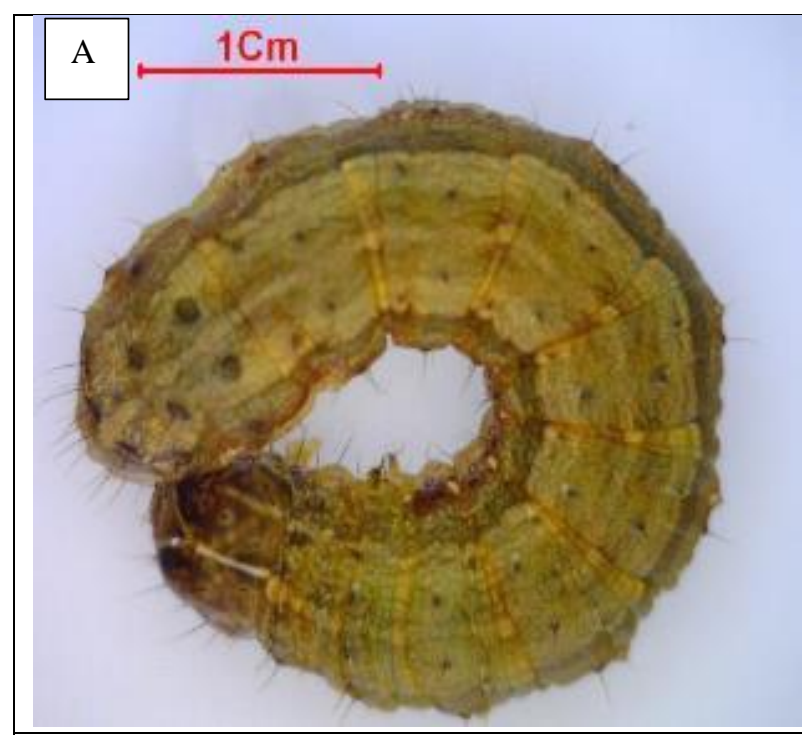

Figure 2a : Non-parasitized S. frugiperda larva.

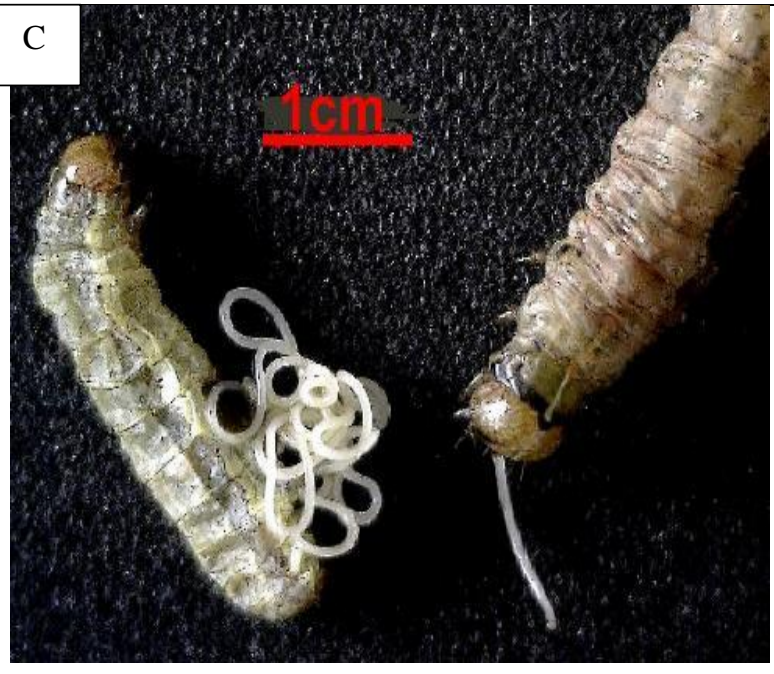

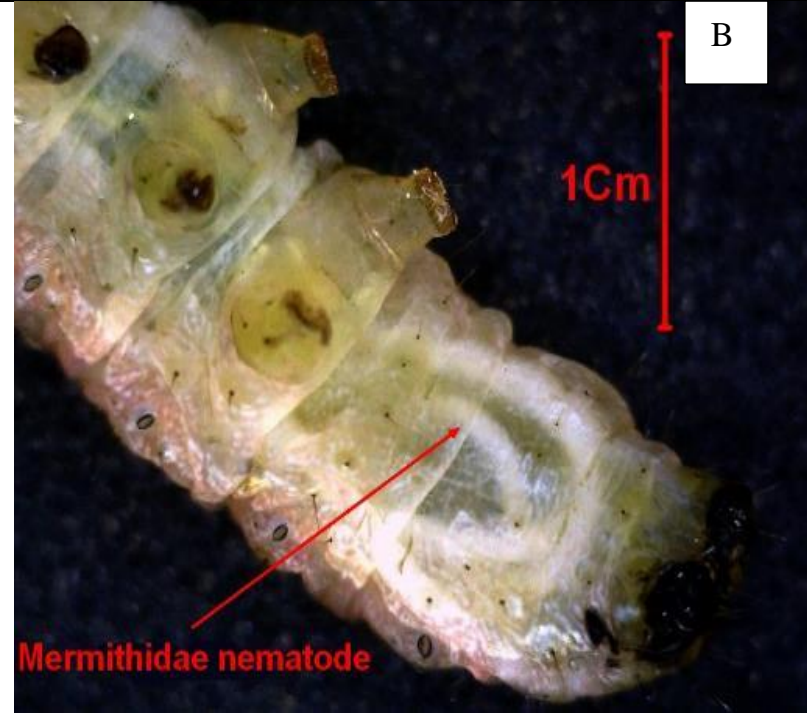

Figure 2b: Parasitic nematode (Hexamermis sp.) inside the body cavity of S. frugiperda larva.

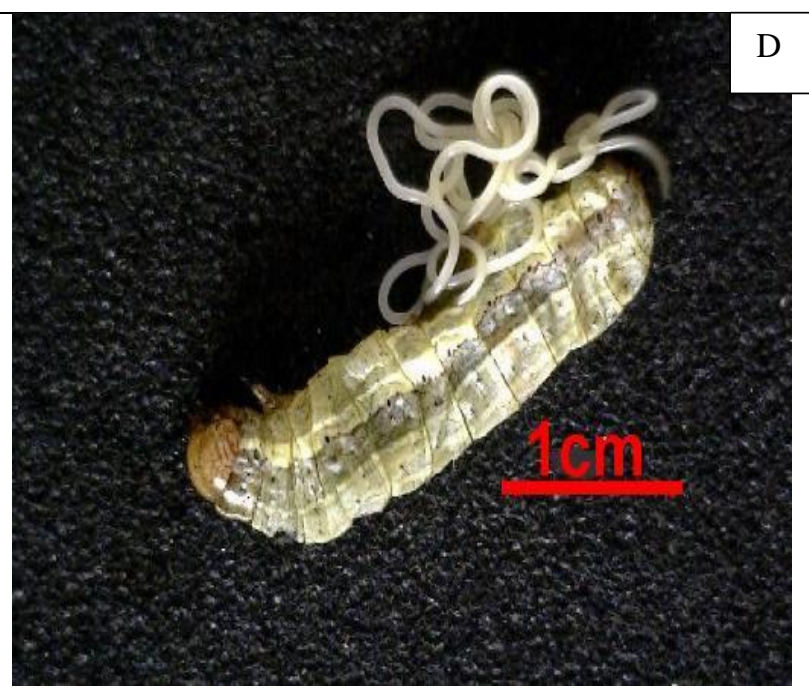

Figure 2c-d : Active emergence of Mermithidae nematodes (Hexamermis sp.) from the body cavity of $S$. frugiperda larvae (either at the level of the cephalic capsule or at the level of the false legs). 


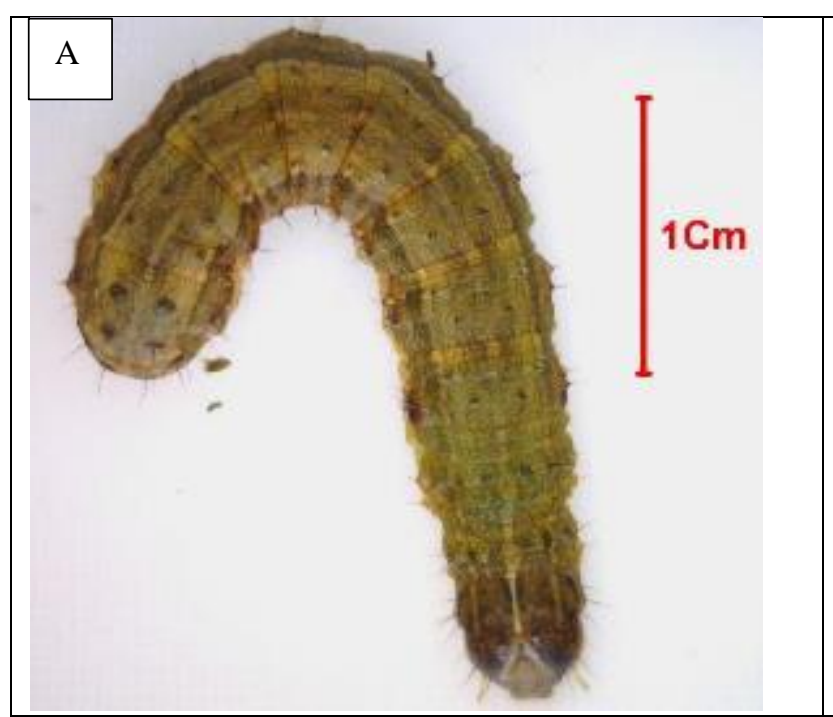

Figure 3a: Spodoptera frugiperda larva.

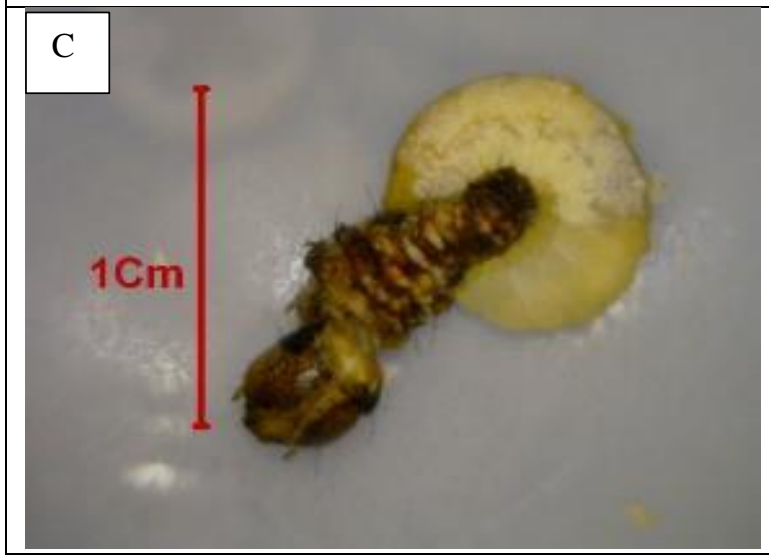

Figure 3c : Parasitoid larvae (Chelonus sp.) sucking the hemolymph from $S$. frugiperda larva.

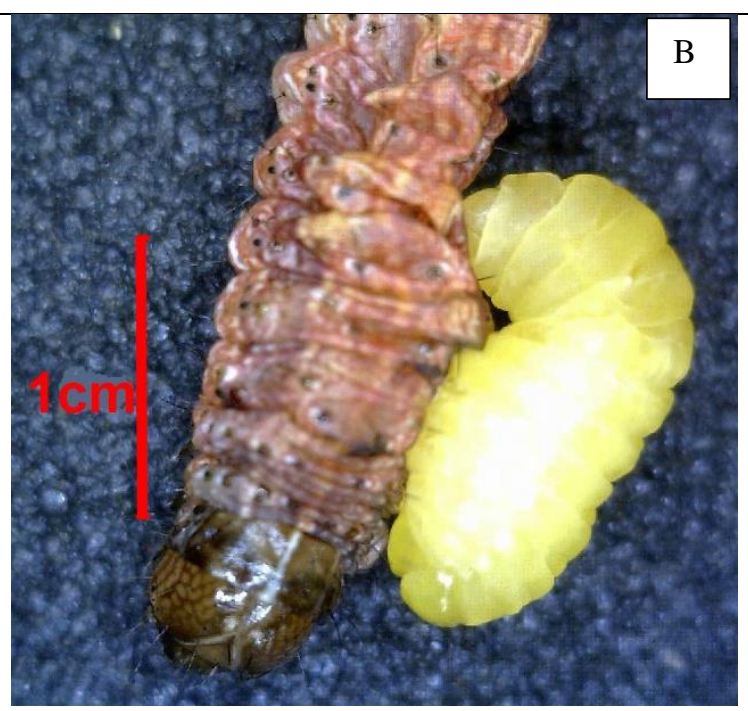

Figure 3b: Parasitoids larva (Chelonus sp.) sucking the hemolymph from $S$. frugiperda larva.

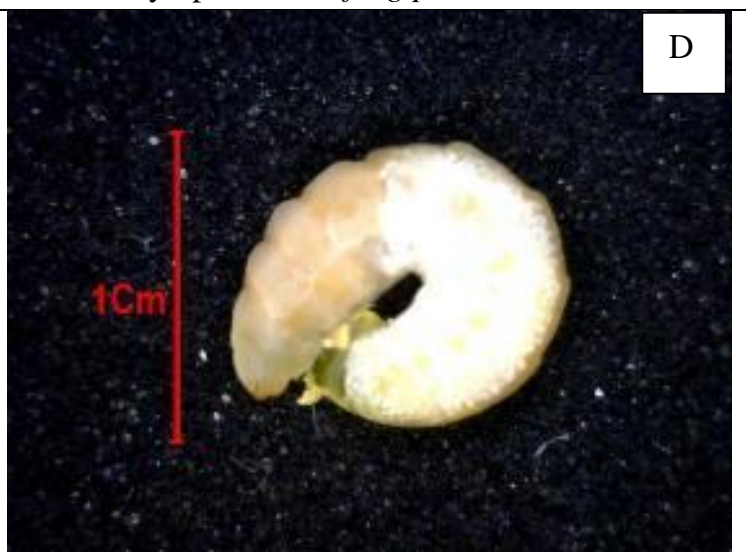

Figure. 3d: Parasitoids larva (Chelonus sp.) alone after sucking the hemolymph from $S$. frugiperda larva.
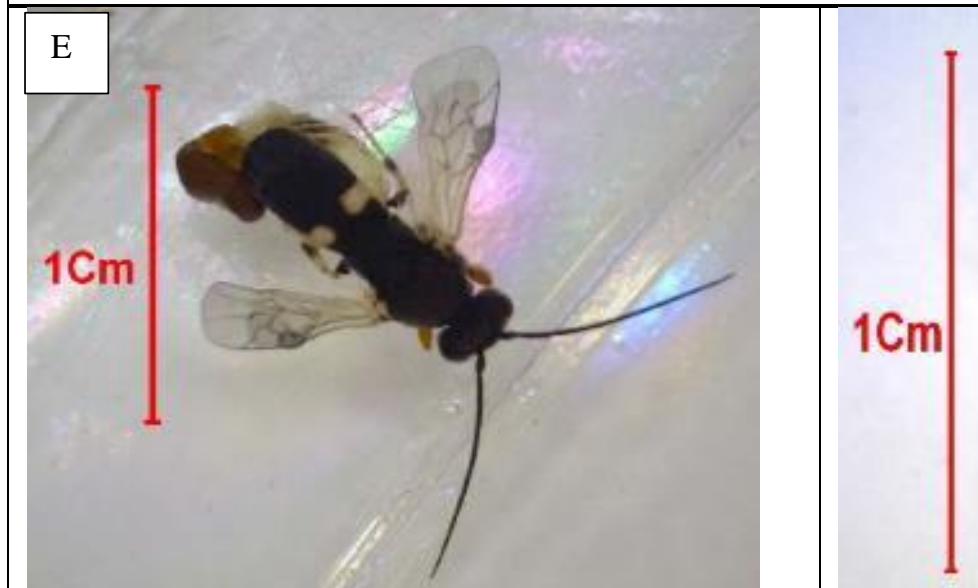

$\mathrm{F}$

Figure 3f: Adult Chelonus sp. able to parasitize S. frugiperda larva.
Figure 3e : Emergence of Chelonus sp. adult parasitoid.

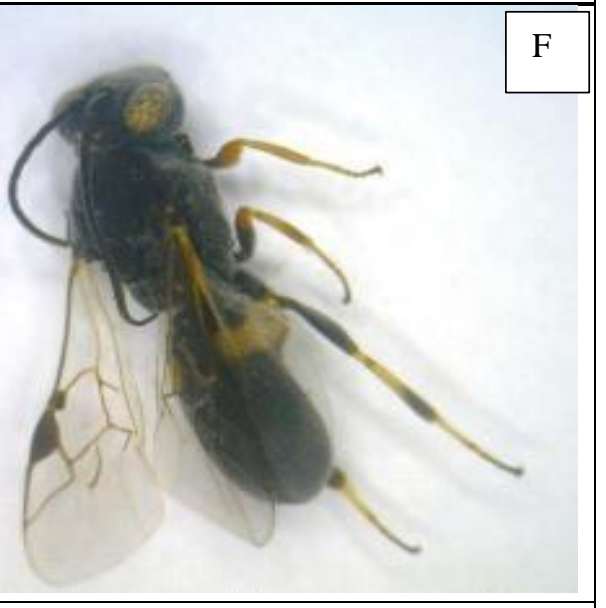




\begin{tabular}{|l|l|l|}
\hline Figure 4a: Adult Campoletis sp. able to parasitize & Figure 4b: Parasitoid larvae (Campoletis sp.) \\
\hline S. frugiperda larva. & newly emerged from S. frugiperda larva. \\
\hline C & & Figure. 4d: Adult of the parasitoid (Campoletis \\
\hline
\end{tabular}

\section{DISCUSSION}

The results show that the total duration of $S$. frugiperda cycle is between 22 and 28 days with an average of 25 days at $25{ }^{\circ} \mathrm{C}$. Which give on average 15 generations a year.Castro and Pitre (1988) have shown that $S$. frugiperda development cycle is between 28 to 38 days when the pest is fed with sorghum and 35 to 45 days when fed with corn. The FAW is a formidable invasive pest as it has a fairly rapid development cycle that varies with temperature (Chapman et al., 2000; Barros et al., 2010b; Jeger et al., 2017). The optimum larval development temperature of $S$. frugiperda is $28^{\circ} \mathrm{C}$, but may be lower for egg-laying and pupation (CABI, 2017). Depending on the host plant and weather conditions, the cycle duration may be different. The pest also has a preference for poaceous, especially maize (Dumas et al., 2015). The results of Castro and Pitre (1988) showed a cycle of 45 days. The generation number per year is 8 , much lower than the annually 15 generations obtained from the results of this study after rearing $S$. frugiperda in the laboratory from September 2017 to September 2018. The number of generations per year of the S.frugiperda has a big impact on yields. Indeed each generation can cause damage to the present crops. It is a pest with a very strong occurrence because of its wide spectrum of host plants. Indeed, larvae feed on leaves and stems of more than 80 plant species (CABI, 2017). This polyphagous 
character can promote the increase in the number of generations observed annually in tropical countries. Depending on the host plant, there are different populations of the $S$. frugiperda with a "C" strain on corn and cotton and a dominant " $\mathrm{R}$ " strain on rice, millet and wild grasses (Groot et al., 2008) .

For the larvae, our results showed that the average duration of larval phase development is 14 days whereas it is 21 days at $25{ }^{\circ} \mathrm{C}$ (Silva et al., 2017) and 11 days at 25 ${ }^{\circ} \mathrm{C}$ (Santos et al., 2003) for larvae fed with maize. The duration of the larval phase depends on the conditions and the host plant. The larval stage is the most dreaded stage of the pest $S$. frugiperda. The damages are caused by larvae that can cause enormous losses in yields that can go until the total destruction of crops. Human consumption of maize is expected to increase by $21 \%(28 \mathrm{Mt})$, especially in developing countries, especially those in Africa where white maize is an essential staple food in many countries (OCDE/FAO, 2016). In sub-Saharan Africa, famine will persist if no effective protective measures are taken to limit the expansion of the FAW. In other words, larvae cause countless damages to coarse grains such as rice and sorghum, but also cotton and vegetable crops (FAO, 2017). Indeed, the longer is the duration of the larval stage, the greater are the losses because the larvae consume a lot, especially during the last four days before pupation (Flanders et al., 2017). As soon as the eggs hatch, the larvae begin to consume the host plant until they pupate. All part of the plant can be consumed (leaf, stem, ear, bud...). The amount ingested increases with the growth of the larvae. The consumption of $S$. frugiperda larvae is most important from the 3rd larval stage and increases until the last one. This can lead to significant yield losses. The pest status of FAW is usually associated with specific developmental stages of the host plant (Barros et al., 2010a). Larvae prefer most often seedlings and young leaves that are more susceptible to damage. In an infested cornfield, older larvae are often housed in the bud of the plant. This position in the bud protects this pest against some auxiliaries (predators and parasitoids) and even some chemicals. Producers have difficulty detecting the pest in these conditions. They only observe the damage. On the ground, the attack of plants with 6-10 leaves is more severe and has more harmful damages. The larva destroys the bud of young plants and prevents their normal development. Maize is more sensitive at the time of inflorescence (Kranz et al., 1981). Eggs are incubated in 5 days ( \pm 1 day). This egg incubation duration depends on the temperature and is between 2 and 10 days (Jeger et al., 2017). For temperatures between 21 and $27{ }^{\circ} \mathrm{C}$ the incubation duration of eggs is between 2 and 4 days (Sparks, 1979).

For the identification of the main stages of development of $S$. frugiperda (egg, larva, nymph and adult), the results show that a female lays oblong eggs grouped on the leaves of the host plant. A spawn contains about near 300 to 400 eggs arranged in layer. Adult female of $S$. frugiperda can lay up to 1500 to 2000 eggs (Kumela et al., 2018). The eggs measure between 0.3 and $0.4 \mathrm{~mm}$. They form a mass consisting of two layers. The egg mass is covered with a felted protective layer of silks from the abdomen of the female (Figure 1b). These observations corroborate those studies on the moth (Capinera, 1999; EPPO, 2015). Indeed, this protective layer makes it difficult to count eggs with a binocular magnifying glass in the laboratory.

After egg hatch, neonate larvae feed on the upper surface of maize leaves without crossing the blade and the lower epidermis remains transparent (Figure 1c). This aspect of the leaves facilitates the recognition of the pest in the field. In laboratory, the similarity observed at the different larval stages is confusing as to their clear distinction (Figure 1d). Which explains the variation of the number of larval stages (5 to 6 ) found in the literature (Santos et al., 2003). As they develop, the larvae of $S$. frugiperda, present four pinaculas arranged in square at the level of the last segment (Figure 1g). Older larvae of this pest possess a « $\mathrm{Y} »$ inverted of lighter color in the cephalic capsule (Figure 1h). These characters are decisive for the 
recognition of larvae according to a number of studies on $S$. frugiperda biology (Passoa, 1991; EPPO, 2015 ). The color of the larvae gets darker as they grow from light green to brown (EPPO, 2015). Nevertheless, the color of the larvae remains an unreliable criterion because it is often random. As for nymphosis, if it takes place in loose soil, the chrysalis is protected by a silk cocoon secreted by the larvae (Figure 1e). On a hard surface, the chrysalid is without a silk cocoon. The chrysalis has three segments at its posterior end. Adults are sexually dimorphic based on color contrast more accentuate in the male (Pogue, 2002). In the laboratory, recognition based only on the color of adults is a criterion that becomes obsolete with time because adults lose their color very quickly in contact with the wall of breeding cages. Moreover, this dimorphism is easily confused with that of other species of the same genus e.g., $S$. exempta or S. littoralis (Reddy, 2017; EPPO, 2015).

To manage the populations of the $S$. frugiperda, control strategies have been mainly adopted; chemical control by use of synthetic products, the genetic control with the use of genetically modified plantes (GMOs) (Bernardi et al., 2014) and biological control through the use of organic extracts (Scapinello et al., 2014; Sosa et al., 2017). The control based into $B$. thuringiensis $(\mathrm{Bt})$ with the formulation of maize-Bt hybrids was also been used for controlling the fall armyworm (Farias et al., 2014; Niu et al., 2017). However, these control methods have limitations because of the resistance developed by this pest (Adamczyk Jr et al., 1997; Bernardi et al., 2017).

Biological control appears as a serious alternative to enhance. As a result, it becomes relevant to exploit the action of the natural enemies of this pest in its environment. Our results show that, despite its recent introduction in West Africa, S. frugiperda already has a large parasite procession that goes from nematodes to hymenopterans. Indeed, nematodes of the genus Hexamermis (Figure 2e) and hymenopterans of the genus Chelonus (Figure 3f) and Campoletis (Figure 4a) were obtained from the larvae of the $S$. frugiperda with an overall parasitism rate of $25.8 \%$. This rate of parasitism is divided between nematodes (13.7\%) and hymenopterans (12.1\%). These hymenopterans belong to the family Braconidae (Chelonus sp.) and ichneumonidae (Campoletis sp.). With a parasitism rate of $10.9 \%$ for Chelonus sp. and $1.2 \%$ for Campoletis sp. These parasitoids and the parasite Hexamermis sp. (13.7\%) are a promising mean for the biological management of the pest. For the first time in West Africa a parasitic nematode and two parasitoid hymenoptera regulate $S$. frugiperda populations. In Africa, five species of parasitoids were recorded from the fall armyworm in three East African countries in 2017 (Sisay et al., 2018). For parasitism of nematodes, specimens up to more than $10 \mathrm{~cm}$ long have been observed inside the L4 stage larvae organism. This infestation would start from the young larvae (neonates) which, dispersing, spend a short time on the ground where they are often in contact with the juvenile nematodes. The latter infesting only during this phase (James et al., 2010; CamposHerrera, 2015), parasitize the larvae through an active entrance through their cuticle. The germs of this nematode grow in the abdomen of the host larvae, which now leads a sluggish life with a marked decrease in its consumption. At maturity, the nematode actively leaves its host either by the cephalic capsule or most often by the false legs of the lower ventral (Figure 2c-2d). A record of four individuals of the parasite per host larvae were sometimes obtained. At the exit of the parasite, the larvae is in the form of a body lying on the place of emergence of the nematode (Figure 2d). After emergence, adult nematodes couple and intertwine to produce offspring that in turn actively seek other host larvae. This phenomenon was observed on isolated nematodes in boxes containing humid sand just after emergence. Adult nematodes have a life span that exceeds 90 days in the laboratory.

The species Chelonus sp. is an ovolarval parasitoid. The Chelonus Panzer genus 
can attack several Lepidoptera including Helicoverpa armigera, Plutella xylostella Phthorimaea operculella, and Hellula undalis (Yousuf and Ray, 2009) .This genus is cosmopolitan and belong to the subfamily of the Cheloninae which includes solitary endoparasitoids koïnobiontes. Koïnobionte parasitoids do not immediately kill their hosts, which appear to follow normal development (Askew and Shaw, 1986). The parasitized larvae continue their development until the exit of the parasitoid. At the time of emergence, the host larvae becomes moribund and is unable to move or feed. Parasitoid, although located on the outside, remains attached to the larvae track and continues to suck the hemolymph (Figure 3b-3c). When the contents of the larvae are emptied, the parasitoid larvae is detached from it and continue its development by secreting a silk cocoon that protects it until the adult emerges. The larvae obtained are pearly white in color and vary in size from 8 to $10 \mathrm{~mm}$. The lifetime of the larvae is 8 to 9 days after which emerges an adult.

The Campoletis sp. species is a larval endoparasitoid that plays an important role in regulating S. frugiperda (Molina-Ochoa et al., 2003; Dequech et al., 2005; Ordóñez-García et al., 2015). The FAW is a natural host of the parasitoid C. flavicincta (Neto et al., 2004; Zanuncio et al., 2013). The larvae of the parasitoid, just out of the larvae of $S$. frugiperda pest starts making his cocoon (9.5 mm long) which allows it to continue his development until the emergence (Figure $4 \mathrm{~b}$ $4 c)$.

In addition to biological control, cultural method with a use of "push-pull" was experienced in East Africa and seems to effectively fight against the larvae of $S$. frugiperda (Midega et al., 2018). Indeed, the establishment of plants attracting the auxiliaries between the rows of the host culture and plants repelling the FAW at the border of the field acts both on the physical and chemical characteristics of the pest. The effectiveness of the "push-pull" can be attributed to the confusion of the pest to detect the host plant. On the other hand, depending on the biology of $S$. frugiperda, the distance between the rows of the crop affects the efficiency of the dispersion of the larvae. Indeed, neonate larvae from hatching eggs disperse by moving on the leaves or hanging from a silk thread they secrete. This dispersion is all the more effective thanks to the action of the wind which causes their oscillation allowing the larvae to land on a nearby plant or on the ground. If the plant nearby differs from the host, the larvae proliferate with difficulty and die by loss of contact with their food. Young larvae are often parasitized by juvenile nematodes leading an active life free searching host. The larvae, by consuming maize leaves are contaminated by ingesting nematode eggs deposited by females. Indeed, the females adult of nematodes leave the ground and rise to the leaves to lay eggs. Active infestation of nematodes through the cuticle of larvae is also possible. Eggs can hatch in the soil and infective juveniles of mermithidae go back vegetation, where they discover and invade their host (Riga, 2004). In this case, nematode enters the digestive tract of the larvae by piercing the cuticle.

A good knowledge of the bio-ecology of the FAW seems necessary for its effective management. Indeed, its appearance in Senegal, the FAW constitutes a new threat to food security because of its high migration capabilities and its damages to corn crops. In Senegal, arthropod pest complex can cause damage in field-grown (Labou et al., 2016a; Diatte et al., 2018b). However, many ecosystems have a great diversity of entomological species that plays an important role in natural regulation (Labou et al., 2017; Tendeng et al., 2017; Diatte et al., 2018a). Very active during the night, adults of the FAW can move up to a distance exceeding $100 \mathrm{~km}$ (FAO, 2017). These migratory performances are manifested by his ability to colonize new environments. S. frugiperda adults from the United States migrated to Georgia from southern Florida over a distance about $600 \mathrm{~km}$ (Nagoshi et al., 2008). In Africa, Comparative molecular analyses of invasive fall armyworm in Togo reveal strong 
similarities to populations from the eastern United States and the Greater Antilles (Nagoshi et al., 2017). Another study confrmed initial indications based on Togo populations of $S$. frugiperda that Florida and the Greater Antilles are the likely source of at least a subset of the African infestation and further suggest an entry point in western Africa (Nagoshi et al., 2018). This suggests that the specimens found in Casamance (in Senegal) in August 2017 would come from the same source. Comparative molecular analyses of the FAW are necessary to determine the origin of the strains found in Senegal.

\section{Conclusion}

Native natural enemies regulate $S$. frugiperda populations. The present study confirms the presence of indigenous natural enemies of the fall armyworm in West Africa.The results show a regulation rate of $25.8 \%$. This natural regulation would be an alternative to the use of often ineffective chemicals against this pest. For the first time in West Africa, a parasitic nematode and two parasitoid hymenoptera regulate $S$. frugiperda populations. The results of this study allow us to conclude that these native natural enemies are a very promising means of control against FAW populations. The use of chemicals to control FAW can be a cause for economic loss due to their high price and inefficiency against $S$. frugiperda, and ecological waste by killing natural enemies and other useful insects. Control methods or agricultural practices that favor the maintenance of native natural enemies are necessary to fight $S$. frugiperda. More research is needed on local factors (crop management) and landscapes (crops and noncrop habitats) that favor parasitoid communities.

\section{COMPETING INTERESTS}

The authors declare that they have no competing interests.

\section{AUTHORS' CONTRIBUTIONS}

ET contributed to the definition of experimental protocols, field data collection, statistical data analysis and article writing. BL contributed to the definition of experimental protocols, statistical analysis of data and the writing of the article. MD contributed to the definition of the experimental protocols and the writing of the article.SD contributed to the definition of the experimental protocols and the writing of the article KD contributed to the coordination of activities, the definition of experimental protocols, statistical data analysis and manuscript correction.

\section{ACKNOWLEDGMENTS}

We thank Student at the following Universities or Institutions Assane Seck Univerty of Ziguinchor (M.S. Edbo, A. Ndiaye, J. Demba, A. Sylla, M. Kane, M. Kambaye, A.S.S. Sall, and D. Manga), A. Coly (ISFAR) and Cheikh A. Diop University of Dakar (N.KC. Sané, A. Dieng and B. Honou) for assistance in laboratory rearing and field collection of insects used in this investigation. We gratefully acknowledge anonymous reviewers for helpful corrections on a previous version of this manuscript before its submission.

\section{REFERENCES}

Adamczyk Jr JJ, Holloway JW, Leonard BR, Graves JB. 1997. Susceptibility of fall armyworm collected from different plant hosts to selected insecticides and transgenic Bt cotton. J. Cotton Sci., 1: 21-28.

Askew RR, Shaw MR. 1986. Parasitoid communities: their size, structure and development. In Insect Parasitoids. 13th Symposium of Royal Entomological Society of London Waage J, Greathead D (ed). Academic Press, London: now Elsevier; 225-264

Baker GL, Capinera JL. 1997. Nematodes and nematomorphs as control agents of grasshoppers and locusts. Mem. Entomol. Soc. Can., 129: 157-211 https://doi.org/10.4039/entm1291711571.

Barros EM, Torres JB, Ruberson JR, Oliveira MD. 2010b. Development of Spodoptera frugiperda on different hosts and damage 
to reproductive structures in cotton: Fall armyworm performance on different hosts. Entomol. Exp. Appl., 137 (3): 237245.DOI: https://doi.org/10.1111/j.15707458.2010.01058.x.

Bernardi D, Bernardi O, Horikoshi RJ, Salmeron E, Okuma DM, Farias JR, do Nascimento, ARB, Omoto C. 2017. Selection and characterization of Spodoptera frugiperda (Lepidoptera: Noctuidae) resistance to MON $89034 \times$ TC1507 $\times$ NK603 maize technology. Crop Prot., 94: 64-68. DOI: https://doi.org/10.1016/j.cropro.2016.11. 026.

Bernardi O, Sorgatto RJ, Barbosa AD, Domingues FA, Dourado PM, Carvalho RA., Martinelli S, Head GP, Omoto C. 2014. Low susceptibility of Spodoptera cosmioides, Spodoptera eridania and Spodoptera frugiperda (Lepidoptera: Noctuidae) to genetically-modified soybean expressing Cry1Ac protein. Crop Prot., 58: 33-40. DOI: https://doi.org/10.1016/j.cropro.2014.01. 001.

Braet Y, Rousse P, Sharkey M. 2012. New data on African Cheloninae (Hymenoptera, Braconidae) show a strong biogeographic signal for taxa with spined propodea. Zootaxa, 1-32.

Brévault T, Ndiaye A. Badiane D, Bal AB, Sembène M, Silvie P, Haran J. 2018. First records of the fall armyworm, Spodoptera frugiperda (Lepidoptera: Noctuidae), in Senegal. Entomol. Gen. 37(2): 129-142. DOI: https://doi.org/10.1127/entomologia/201 $8 / 0553$.

CABI. 2017. Scientists discover new cropdestroying Armyworm is now 'spreading rapidly' in Africa. Wallingford, UK: CABI. http://www.cabi.org/news-andmedia/2017/scientists-discover-newcrop-destroying-armyworm-is-nowspreading-rapidly-in-africa/. http://www.cabi.org/.

Campos-Herrera R. 2015. Nematode Pathogenesis of Insects and Other Pests
(1 $\quad$ edn). Springer International Publishing, Cham.

Capinera JL. 1999. Fall Armyworm, Spodoptera frugiperda (J.E. Smith) (Insecta: Lepidoptera: Noctuidae). Featured Creatures from the Entomology and Nematology Department, Florida Cooperative Extension Service. http://entomology.ifas.ufl.edu/creatures.

Castro MT, Pitre HN. 1988. Development of Fall Armyworm, Spodoptera frugiperda, from Honduras and Mississippi on Sorghum or Corn in the Laboratory. Fla. Entomol. 71(1): 49-56. DOI: https://doi.org/10.2307/3494892.

Chapman JW, Williams T, Martínez AM, Cisneros $\mathrm{J}$, Caballero $\mathrm{P}$, Cave RD, Goulson D. 2000. Does cannibalism in Spodoptera frugiperda (Lepidoptera: Noctuidae) reduce the risk of predation? Behav. Ecol. Sociobiol., 48(4): 321-327.

Day R, Abrahams P, Bateman M, Beale T, Clottey V, Cock M, Colmenarez Y, Corniani N, Early R, Godwin J, Gomez J, Moreno PG, Murphy ST, OppongMensah B, Phiri N, Pratt C, Silvestri S, Witt A. 2017. Fall Armyworm: Impacts and Implications for Africa. Outlooks Pest Manag., 28 (5):196-201. DOI: https://doi.org/10.1564/v28_oct_02.

Dequech ST, da Silva RF, Fiuza LM. 2005. Interaction between Spodoptera frugiperda (JE Smith) (Lepidoptera: Noctuidae), Campoletis flavicincta (Ashmead) (Hymenoptera: Ichneumonidae) and Bacillus thuringiensis aizawai, in laboratory. Neotrop. Entomol., 34 (6): 937-944. DOI: http://dx.doi.org/10.1590/S1519566X2005000600010.

Diatte M, Brevault T, Sall-Sy D, Diarra K. 2018a. Dynamique des parasitoïdes larvaires de Helicoverpa armigera (Lepidoptera: Noctuidae) dans la zone des Niayes au Sénégail. Int. J. Biol. Chem. Sci., 12(1): 392-401. DOI: https://doi.org/10.4314/ijbcs.v12i1.31.

Diatte M, Brévault T, Sylla S, Tendeng E, Sall-Sy D, Diarra K. 2018b. Arthropod pest complex and associated damage in 
field-grown tomato in Senegal. Int. $J$. Trop. Insect Sci., 38(3): 243-253.DOI: https://doi.org/10.1017/S1742758418000 061.

Dumas P, Legeai F, Lemaitre C, Scaon E, Orsucci M, Labadie K, Gimenez S, Clamens AL, Henri H, Vavre F, Aury JM, Fournier P, Kergoat GJ, d'Alençon E. 2015. Spodoptera frugiperda (Lepidoptera: Noctuidae) host-plant variants: two host strains or two distinct species? Genetica, 143(3): $305-$ 316.DOI:https://doi.org/10.1007/s10709015-9829-2.

EPPO. 2015. Bulletin OEPP/EPPO: Spodoptera littoralis, Spodoptera litura, Spodoptera frugiperda, Spodoptera eridania. $45(3)$ : 41. DOI: 10.1111/epp. 12258 .

FAO. 2017. Note d'information de la FAO sur la chenille légionnaire d'automne en Afrique. OFAO 2017, 8p.Note d'information de la FAO.reliefweb.int/.../.

Farias JR, Andow DA, Horikoshi RJ, Sorgatto RJ, Fresia P, dos Santos AC, Omoto C. 2014. Field-evolved resistance to Cry1F maize by Spodoptera frugiperda (Lepidoptera: Noctuidae) in Brazil. Crop Prot., $\quad$ 64: 150-158.DOI: https://doi.org/10.1016/j.cropro.2014.06. 019.

Flanders K, Don B, Patricia C. 2017. Management of Fall Armyworm in Pastures and Hayfields. Ala. Coop. Ext. Syst. Ala. AM Univ. Auburn Univ., 8p.

Goergen G, Kumar PL, Sankung SB, Togola A, Tamò M. 2016. First Report of Outbreaks of the Fall Armyworm Spodoptera frugiperda (JE Smith) (Lepidoptera, Noctuidae), a New Alien Invasive Pest in West and Central Africa. PloS One, 11(10): e0165632.DOI: doi:10.1371/journal.pone.0165632

Groot AT, Marr M, Schöfl G, Lorenz S, Svatos A, Heckel DG. 2008. Host strain specific sex pheromone variation in Spodoptera frugiperda. Front. Zool., 5(1): $20 . \quad$ DOI: https://doi.org/10.1186/1742-9994-5-20.
James B, Atcha-Ahowé C, Godonou I, Baimey H, Goergen G, Sikirou R, Toko M. 2010. Gestion integree des nuisibles en production maraichere: guide pour les agents de vulgarisation en Afrique de l'Ouest. IITA, Ibadan, Nigeria. 120 p.

Jeger M , Bragard C ,Caffier D, Candresse T, Chatzivassiliou E, Dehnen-Schmutz K, Gilioli, G, Gregoire J, Jaques Miret JA, Navarro MN, Niere B, Parnell S, Potting R, Rafoss T, Rossi V, Urek G, Van Bruggen A, Van der Werf W, West J, Winter S, Gardi C, Aukhojee M, MacLeod A. 2017. Pest categorisation of Spodoptera frugiperda. EFSA J., 15 (7): 1-37.

DOI: https://doi.org/10.2903/j.efsa.2017.4927.

Kranz J, Schmutterer H, Koch W. 1981. Maladies, Ravageurs et Mauvaises Herbes des cultures Tropicales., 717p.

Kumela T, Simiyu J, Sisay B, Likhayo P, Mendesil E, Gohole L, Tefera T. 2018. Farmers' knowledge, perceptions, and management practices of the new invasive pest, fall armyworm (Spodoptera frugiperda) in Ethiopia and Kenya. Int. J. Pest Manag., 65 (1): 1-9. DOI:

https://doi.org/10.1080/09670874.2017.1 423129.

Labou B, Bordat D, Brevault T, Diarra K. 2016a. Importance de la" Teigne du chou" dans les Niayes au Sénégal: interrelations avec la température et les cultivars utilisés. Int. J. Biol. Chem. Sci., 10(2): 706-721. DOI: 10.4314/ijbcs.v10i2.21.

Labou B, Bordat D, Brevault T, Diarra K. 2017. Spatiotemporal distribution and impact of diamondback moth parasitoids in the Dakar Niayes in Senegal. Int. J. Biol. Chem. Sci., 11(3): 1288-1298.DOI: https://doi.org/10.4314/ijbcs.v11i3.28.

Labou B, Brévault T, Bordat D, Diarra K. 2016b. Determinants of parasitoid assemblages of the diamondback moth, Plutella xylostella, in cabbage farmer fields in Senegal. Crop Prot., 89: 611.DOI: doi.org/10.1016/j.cropro.2016.06.018. 
Midega CAO, Pittchar JO, Pickett JA, Hailu GW, Khan ZR. 2018. A climate-adapted push-pull system effectively controls fall armyworm, Spodoptera frugiperda (J E Smith), in maize in East Africa. Crop Prot., 105: 10-15.DOI: https://doi.org/10.1016/j.cropro.2017.11. 003.

Molina-Ochoa J, Carpenter JE, Heinrichs EA, Foster JE. 2003. Parasitoids and parasites of Spodoptera frugiperda (lepidoptera: noctuidae) in the Americas and Caribbean basin: an inventory. Fla. Entomol., 86(3): 254-289. DOI: https://doi.org/10.1653/0015-4040 (2003)086[0254: PAPOSF] 2.0.CO;2.

Nagoshi RN, Goergen G, Tounou KA, Agboka K, Koffi D, Meagher RL. 2018. Analysis of strain distribution, migratory potential, and invasion history of fall armyworm populations in northern SubSaharan Africa. Sci. Rep., 8 (11):110.DOI: https://doi.org/10.1038/s41598018-21954-1.

Nagoshi RN, Koffi D, Agboka K, Tounou KA, Banerjee R, Jurat-Fuentes JL, Meagher RL. 2017. Comparative molecular analyses of invasive fall armyworm in Togo reveal strong similarities to populations from the eastern United States and the Greater Antilles (RNC Guedes, Ed.). PLOS ONE 12(7): 1-15. DOI: e0181982 https://doi.org/10.1371/journal.pone.018 1982.

Nagoshi RN, Meagher RL, Flanders K. Gore J, Jackson R, Lopez J, Armstrong JS, Buntin G D, Sansone C, Leonard BR. 2008. Using Haplotypes to Monitor the Migration of Fall Armyworm (Lepidoptera: Noctuidae) Corn-Strain Populations from Texas and Florida. $J$. Econ. Entomol., 101(3): 742-749.

Neto M da Costa F, Cruz I, Zanuncio JC, Silva CHO,Picanço MC. 2004. Parasitism by Campoletis flavicincta on Spodoptera frugiperda in corn. Pesqui. Agropecuária Bras., 39(11):1077-1081.
Nickle WR. 1972. A contribution to our knowledge of the Mermithidae (Nematoda). J. Nematol., 4(2):113-146.

Niu Y, Head GP, Price PA, Huang F. 2017. Inheritance and fitness costs of Cry1A.105 resistance in two strains of Spodoptera frugiperda (J.E. Smith). Crop Prot, 110: 229-235. DOI: https://doi.org/10.1016/j.cropro.2017.06. 022.

OCDE/FAO. 2016. Perspectives agricoles de l'OCDE et de la FAO 2016-2025, Éditions OCDE, Paris.DOI: http://dx.doi.org/10.1787/agr_outlook2016-fr. Organization for Economic Cooperation \& Development, Paris.

Ordóñez-García M, Rios-Velasco C, Berlanga-Reyes DI, Acosta-Muñiz CH, Salas-Marina, MÁ, Cambero-Campos OJ. 2015. Occurrence of Natural Enemies of Spodoptera frugiperda (Lepidoptera: Noctuidae) in Chihuahua, Mexico. Fla. Entomol., 98(3): 843-847. DOI: https://doi.org/10.1653/024.098.0305.

Passoa S. 1991. Color identification of economically important Spodoptera larvae in Honduras (Lepidoptera: Noctuidae). Insect Mund, 5 (3): 185-195.

Pogue MG. 2002. A world revision of the genus Spodoptera Guenée :( Lepidoptera: Noctuidae). Mem of the Americ Entomol Soc, 43: 1-201. https://trove.nla.gov.au/version/3709792 3. Philadelphia.

Reddy GVP. 2017. Integrated management of insect pests on canola and other Brassica oilseed crops (1edn). CABI: Boston, MA.

Riga E. 2004. Orientation Behaviour. In Nematode behaviour. Gaugler R, Bilgrami AL(ed). CABI Publishing, Wallingford, Oxfordshire; 63-81.

Santos LM dos, Redaelli LR, Diefenbach LMG, Efrom CFS. 2003. Larval and pupal stage of Spodoptera frugiperda (JE Smith) (Lepidoptera: Noctuidae) in sweet and field corn genotypes. Braz. J. Biol., 63(4): 627-633. 
Scapinello J, Oliveira JV de, Chiaradia LA, Tomazelli Junior O, Niero R Dal Magro J. 2014. Insecticidal and growth inhibiting action of the supercritical extracts of Melia azedarach on Spodoptera frugiperda. Rev. Bras. Eng. Agríc. E Ambient., 18(8).866-872. DOI: https://doi.org/10.1590/1807-

1929/agriambi.v18n08p866-872.

Silva DM.da, Bueno A de F, Andrade K, Stecca $\mathrm{C}$ dos S, Neves PMOJ, Oliveira MCN.de. 2017. Biology and nutrition of Spodoptera frugiperda (Lepidoptera: Noctuidae) fed on different food sources. Sci. Agric., 74(1): 18-31. DOI: https://doi.org/10.1590/1678-992x-20150160.

Sisay B, Simiyu J, Malusi P, Likhayo P, Mendesil E, Elibariki N, Wakgari M, Ayalew G, Tefera T. 2018. First report of the fall armyworm, Spodoptera frugiperda (Lepidoptera: Noctuidae), natural enemies from Africa. J. Appl. Entomol., 142(8): 800-804. DOI: https://doi.org/10.1111/jen.12534.

Sosa A, Costa M, Salvatore A, Bardon A, Borkosky S,Vera N. 2017. Insecticidal effects of eudesmanes from Pluchea sagittalis (Asteraceae) on Spodoptera frugiperda and Ceratitis capitata. Int. J. Environ. Agric. Biotechnol., 2(1): 361369.DOI https://doi.org/10.22161/ijeab/2.1.45.

Sparks AN.1979. A Review of the Biology of the Fall Armyworm. Fla. Entomol. 62(2): $\quad 82-87 . \quad$ DOI: https://doi.org/10.2307/3494083.
Tendeng E, Labou B, Djiba S, Diarra K. 2017. Actualisation de l'entomofaune des cultures maraîchères en Basse Casamance (Sénégal). Int. J. Biol. Chem. Sci., 11(3): 1023-1028.DOI: https://doi.org/https://dx.doi.org/10.4314 /ijbcs.v11i3.7.

Van Achterberg C. 1990. Illustrated key to the subfamilies of the Holarctic Braconidae (Hymenoptera: Ichneumonoidea). Zool. Med. Leiden, 64(1):1-20.DOI https://doi.org/15.V.1990:1-20, figs. 126.

Yousuf M, Ray P. 2009. Record of Chelonus panzer (Braconidae: Cheloninae) from central India. J. Biopestic., 2(2): 145149.

Yu SJ. 1991. Insecticide resistance in the fall armyworm, Spodoptera frugiperda (J. E. Smith). Pestic. Biochem. Physiol., 39(1): 84-91.

DOI: https://doi.org/10.1016/0048-3575 (91)90216-9.

Zanuncio JC, Matos Neto FDC, Tavares WDS, Cruz I, Leite GLD, Serrão JE. 2013. Functional and numerical responses and reproduction of Campoletis flavicincta parasitizing Spodoptera frugiperda caterpillars. Acta Sci. Agron., 35(4): 419426.DOI:https://doi.org/10.4025/actascia gron.v35i4.15871. 